DOI 10.31558/2075-2970.2018.35-36.9

УДК 81`42:811.112.2

(C) А. В. Ізмалкова

(Вінниця)

\title{
МОВНІ ЗАСОБИ ВИРАЖЕННЯ ТАКТИКИ «АКЦЕНТУВАННЯ УВАГИ НА ПОТРЕБАХ ПОКУПЦЯ» В РЕКЛАМНОМУ ДИСКУРСІ
}

Стаття присвячена дослідженню мовних засобів вираження комунікативної тактики «акцентування уваги на потребах покупця» як однієї з тактик реалізації комунікативної стратегії маніпуляції в рекламному дискурсі на прикладі рекламних текстів автомобілів німецькою та англійською мовами. Метою дослідження є виявлення структурних та комунікативних особливостей текстів реклами автомобілів німецькою та англійською мовами. Специфіка досліджуваної теми передбачає застосування контекстуально-інтерпретаційного та прагматичного аналізу тексту для встановлення мотивів і цілей автора рекламних текстів, а також оцінки ефективності впливу обраної комунікативної тактики на реципієнта; контент-аналізу для виявлення частоти використання окремих мовних засобів. У результаті дослідження були виділені та охарактеризовані структурні та комунікативні особливості текстів реклами автомобілів німецькою та англійською мовами, зокрема були проаналізовані лексичні, синтаксичні та стилістичні засоби, характерні для тактики «акцентування уваги на бажаннях покупця» при реалізації стратегії маніпуляції.

Ключові слова: комунікативна стратегія, комунікативна тактика, рекламний дискурс, рекламний текст, мовна маніпуляція, потреби

Протягом багатьох століть реклама супроводжує людину в усіх сферах їі життя. Вважається, що реклама виникла ще в античні часи як один з видів масової комунікації та слугувала інструментом масового розповсюдження інформації задля регулювання суспільних відносин та координації діяльності суспільства на етапі урбанізації (Ученова, 1999, с. 18-19).

Переломним моментом в історії розвитку реклами стала середина XIX століття, коли на фоні масового виробництва товарів в європейських країнах почало формуватися суспільство споживання, а реклама стала невід’ємною частиною маркетингу (Ученова, 1999, с. 110-136).

У сучасному суспільстві реклама відіграє роль зручного інструмента, який виконує широкий спектр завдань: від інформування та впровадження певних політичних, релігійних, культурних думок та ідей у свідомість суспільства до сприяння збуту товарів, створення попиту на товар або послугу та отримання прибутку. Через це в останній час інтерес до вивчення реклами, а разом з нею і рекламного дискурсу, особливо його маніпулятивних властивостей, постійно зростає.

Реклама виступає об’єктом дослідження багатьох наук, таких як лінгвістика, соціологія, психологія, культурологія, економіка та ін. 3 лінгвістичної точки зору реклама та рекламний дискурс досліджується низкою багатьох науковців. Н. Яніх розглядає особливості планування 
Ізмалкова А. B.

Мовні засоби Вираження тактики «акцентування уваги

на потребах покупия» 6 рекламному дискурсі

та модель рекламної комунікації, аналізує тексти реклами німецькою мовою на рівні лексики, синтаксису, граматики та фразеології, зв'язок тексту та зображення в рекламі. Г. Майєрс досліджує зв'язок мови тексту з їх соціальним контекстом, Г. Кук аналізує дискурс рекламних оголошень англійською мовою з точки зору як мови, так і контексту комунікації; Х. Кафтанджиєв досліджує лінгвістичні та екстралінгвістичні особливості заголовків та основних текстів реклами, а також розкриває поняття рекламної стратегії та тактики. Однак, незважаючи на популярність цієї теми, в наукових роботах досі відсутнє чітке розділення комунікативних стратегій і тактик, що використовуються при реалізації рекламного дискурсу, а також недостатнім є дослідження лексичних, синтаксичних та стилістичних засобів, характерних для тієї чи іншої комунікативної тактики, що обумовлює новизну цього дослідження.

Метою статті є виявлення структурних та комунікативних особливостей текстів реклами автомобілів німецькою та англійською мовами в рамках «тактики акцентування уваги на потребах покупця» як однієї з тактик комунікативної стратегії маніпуляції.

Для досягнення цієї мети були поставлені такі завдання:

1) вивчити комунікативні особливості тактики акцентування уваги на потребах покупця;

2) скласти корпус текстів реклами автомобілів, в яких використовується стратегія акцентування уваги на потребах покупця;

3) проаналізувати структуру рекламних текстів;

4) виділити та розглянути особливості лексичних одиниць, характерних для тактики «акцентування уваги на потребах покупця»;

5) дослідити синтаксичні взаємозв'язки в рекламі;

6) проаналізувати стилістичні засоби, використані в рекламних текстах автомобілів.

Об’єктом дослідження є тексти реклами автомобілів німецькою та англійською мовами.

Предметом дослідження є мовні засоби вираження тактики «акцентування уваги на потребах покупця» при реалізації комунікативної стратегії маніпуляції в рекламі автомобілів на лексичному, синтаксичному та стилістичному рівнях.

Матеріалом дослідження стали 60 текстів реклами автомобілів німецькою мовою (17 540 знаків) та 60 текстів англійською мовою (15 889 знаки) з журналів «Der Spiegel», «Focus», «Stern» та ін. (німецькою мовою) та «The Economist», «NewStatesman» та ін. (англійською мовою) за період 2014-2017 років.

У сучасному суспільстві з перенасиченим схожими за якостями товарами ринком перед рекламістом постає потреба завоювати інтерес споживача. Найчастіше це відбувається шляхом встановлення зв'язку між певними суспільними цінностями, які викликають позитивні 
емоції у реципієнта, та придбанням товару (Janich, 2012, с. 229-230). Реклама повинна не просто звертати увагу на товар, а схиляти реципієнта до думки про його беззаперечну важливість для вдоволення тієї чи іншої потреби та спонукати до купівлі (Гулак, 2004, с. 11-19).

Сприйняття людини сильно залежить від суб'єктивних очікувань. Чим важливіше щось для особи, тим з більшою вірогідністю вона зверне на це увагу (Spieß, 2008, с. 2-3). 3 огляду на це проводиться аналіз потреб людини, що стає основою рекламного тексту. В разі, якщо такі потреби відсутні, ілюзія невдоволення потреби створюється штучно за допомогою певних рекламних технік, після цього увага акцентується на можливості задовольнити потребу реципієнта за допомогою придбання рекламованого товару. Ілюзія невдоволення потреби і $є$ поштовхом до дії, мотивом купівлі (Kirchler, 1999, с. 227-228; Попова, 2002, с. 281).

Для виділення окремих підходів, які використовуються при складанні рекламних текстів, необхідно чітко розділити потреби людини. Найбільш вживаною є класифікація потреб людини за пірамідою Маслоу, у якій найважливішими є фізичні потреби (дихання, їжа, сон і т. ін.), що знаходяться в основі піраміди, за ними йдуть потреба в безпеці, соціальні потреби, потреба в повазі та потреба в самореалізації (на вершині піраміди). Згідно з точкою зору А. Х. Маслоу в першу чергу людина задовольняє потреби, які знаходяться в основі піраміди, і лише тоді, коли вони повністю задовільнені, переходить до наступної категорії потреб. Так, наприклад, людина починає прагнути задовольнити свою потребу в безпеці лише тоді, коли в неї задовільнені всі фізичні потреби (Moslow, 1970, с. 35-46, 97-98).

Говорячи про рекламу, необхідно також враховувати, що для кожного окремого товару актуальним буде окремий набір потреб. Таким чином, фізичні потреби не будуть актуальними для реклами автомобіля. Однак слід враховувати, що, з одного боку, чим нижче за пірамідою знаходяться потреби, тим більший ефект вони будуть мати на реципієнта, але, з іншого боку, якщо певні потреби вже задовільнені, реципієнт може взагалі не сприйняти рекламу, яка намагається актуалізувати такі потреби. Тому при складанні реклами важливо спочатку визначити цільову аудиторію та актуальні для них потреби.

На сьогоднішній день автомобіль для суспільства став не просто поєднанням технічних елементів, яке слугує для переміщення людей, але й предметом гордості його власника. Окрім прямих функцій автомобіля споживач очікує отримати від нього такі додаткові суспільні переваги, як вираження своєї індивідуальності, демонстрацію свого статусу через статус автомобіля, повагу інших осіб тощо. Не менш важливим очікуванням від автомобіля також вважається безпека та надійність.

Для актуалізації в реципієнта певної потреби використовується тактика “акцентування уваги на потребах покупця". Враховуючи вищезазначені очікування, в ході дослідження рек- 
Ізмалкова А. В.

Мовні засоби Вираження тактики «акцентування уваги

на потребах покупия» 6 рекламному дискурсі

лами автомобілів німецькою та англійською мовами в рамках тактики “акцентування уваги на потребах покупця” були виділені такі підходи до створення рекламного тексту:

1) акцентування уваги на високому статусі автомобіля, який реалізує потреби людини в повазі та самореалізації;

2) акцентування уваги на безпеці та надійності, які реалізують потребу людини в безпеці;

Оскільки автомобіль часто вважається предметом розкоші, акцентування уваги на його високому статусі можна назвати одним з найдієвіших, а тому найрозповсюдженіших підходів до складання рекламного тексту. Такий підхід вказує реципієнту на можливість реалізувати потреби в повазі та самоствердженні шляхом придбання рекламованого автомобіля.

3 лінгвістичної точки зору акцентування уваги на високому статусі автомобіля знаходить вираження на лексичному, стилістичному та синтаксичному рівнях. Головну роль при цьому відіграють лексичні засоби (такі як прикметники, іменники, словосполучення тощо, які вказують на неповторність, вишуканість, статусність автомобіля), напр.:

нім. Das Beste kennt keine Alternative. Die neue C-Klasse. Ab 15. März bei ihrem MercedesBenz Partner. Souverän im Auftritt. Einzigartig im Details. Die neue C-Klasse überzeugt nicht nur mit ihrem sportlichen Design in effizienter_Leichtbauweise, sondern auch durch zahlreiche innovative Assistenzsysteme - sowie einen großzügigen, luxuriös gestalteten Innenraum, der den Maßstab ihrer Klasse neu definiert. (Der Spiegel № 11, 2014) 'Краще не знає альтернатив. Новий С-клас. 315 березня у Вашого партнера Mercedes-Benz. Незрівнянний за зовнішнім виглядом. Унікальний у деталях. Новий С-Клас вражає не тільки своїм спортивним дизайном за рахунок ефективної легкої конструкції, але й численними інноваційними системами допомоги - а також просторим, розкішним дизайном інтер'єру, який змінює стандарт свого класу'.

В цьому прикладі для акцентування уваги на статусі автомобіля були використані такі лексичні засоби: субстантивований прикметник das Beste 'краще', прикметники souverän 'незрівнянний', einzigartig 'унікальний', які наголошують на неповторності автомобіля, виділяють його та його власника поміж інших, і таким чином піднімають його престижність, підносять власника автомобіля над іншими; іменникове словосполучення sportliches Design 'спортивний дизайн', яке створює асоціацію з успішними учасниками автомобільних перегонів і робить ілюзію успішності власника автомобіля; іменникове словосполучення großzügiger, luxuriös gestalteter Innenraum 'просторий, розкішний дизайн інтер'єру', яке підкреслює гарний, престижний зовнішній вигляд рекламованого товару Усі вищевказані характеристики, на думку потенційного покупця, повинні підвищити рівень поваги до нього.

Окрім того, в прикладі зустрічається іменник Design 'дизайн', запозичений з англійської мови, та іменник Details 'деталі', запозичений з французької мови. Іншомовні слова відігра- 
ють особливу роль у рекламі, оскільки вони носять іміджевий характер, роблять продукт більш інтернаціональним і модним в очах реципієнта. Однак слід враховувати, що залежно від рівня володіння реципієнтом іноземною мовою іншомовна лексика може викликати різні асоціації, що може привести до неправильного розуміння тексту або взагалі відсутності його розуміння (Janich, 2012, с. 40). При цьому використання іншомовної лексики в німецькій мові зустрічаєтеся частіше, ніж в англійській. Це може бути пов'язано з тим, що англійська мова $\epsilon$ міжнародною, тому ії̈ використання в таких мовах, як німецька - це дуже розповсюджене явище.

У англомовній рекламі Ford SYNC 3 використовуються прикметники, які вказують на ексклюзивність деталей автомобіля (exclusive 'ексклюзивний’, ипіquе 'унікальний', premium 'елітний'), а також прикметник leather 'шкіряний'. Використання назв дорогих матеріалів (leather 'шкіра', gold ‘золото', silver 'срібло' тощо) розповсюджене в англомовній рекламі, на відміну від німецькомовної:

англ. ... Exclusive alloy wheels

$\underline{\text { Unique vignale styling }}$

Premium leather seats (NewStatesman 21-27 Oct 2016)

'Ексклюзивні диски

Унікальний стиль Vignale

Елітні шкіряні сидіння'.

Також в англомовній рекламі був знайдений ряд рекламних текстів з використанням слова lихигу 'розкіш'.

англ. Time to redefine luxury.

The All New Genesis. (The Economist Dec 6-12 2014)

'Час надати нове визначення розкоші.

Новий Genesis'.

англ. DESIGNED TO GIVE YOU THE LUXURY OF TIME (New Statesman 13-19 Nov 2015) 'Створений для того, щоб надати Вам розкіш часу'.

У рекламі FORD MONDEO акцент зроблено на витонченому дизайні автомобіля за допомогою таких лексичних засобів, як: іменники (style 'стиль', sophistication 'витонченість', head-turner 'той, що звертає на себе увагу'), іменникові словосполучення (sleek curves 'витончені вигини', bold lines 'сміливі лініi', elegant interior ‘елегантний інтер'єр'), прикметники (sophisticated 'витончений', refined 'покращений'):

англ. Style with sophistication.

\section{ALL-NEW FORD MONDEO}

Ford Dynamic LED Headlights 
Ізмалкова А. B.

Мовні засоби Вираження тактики «акцентування уваги

на потребах покупия» 6 рекламному дискурсі

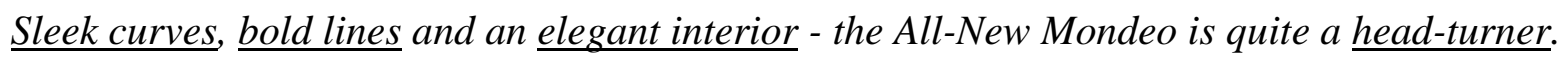

But it isn't just the looks that are refined: the technology you'll find inside is equally sophisticated... (NewStatesman 28 Nov - 4 Dec 2014)

'Витончений стиль.

HOВИЙ FORD MONDEO

Динамічні світлодіодні фари Ford.

Витончені вигини, сміливі лінії та елегантний інтер'єр - новий Mondeo справді звертає на себе увагу.

Але покращений не тільки зовнішній вигляд: технологія, яку Ви знайдете всередині також витончена...'.

Для актуалізації в реципієнта потреби в безпеці в англійській мові використовується повторення таких лексичних засобів, як іменники safety 'безпека' та convenience 'впевненість', а також дієслово protect ‘захищати’ та прикметник safe ‘безпечний', напр.:

англ. ... The new Tucson is all about change. It's the all-new compact SUV that overtakes the status quo with its all-round excellence. Throughly rewarding drivability, unrivalled interior space, and advanced technologies that extend safety, convenience and passenger comfort... (The Economist Oct 10-16 2015) 'новий Tucson - це, перш за все, зміни. Це абсолютно новий компактний позашляховик, який випереджає статус кво своєю всебічною досконалістю. Відмінна керованість, неперевершений інтер'єр і передові технології, які підвищують безпеку, впевненість і комфорт пасажирів...'.

англ. ALL-NEW FORD MONDEO (...)

Take the rear seatbelts with built-in airbags that give your passengers unprecedented protection... (NewStatesman 28 Nov - 4 Dec 2014).

\section{'АБСОЛЮТНО НОВИЙ FORD MONDEO}

Скористайтесь заднім ременями безпеки з вбудованими подушками безпеки, які надають Вашим пасажирам безпрецедентний захист'.

В німецькій мові з метою акцентування уваги на безпеці використовують повторення іменника Sicherheit 'безпека', напр.:

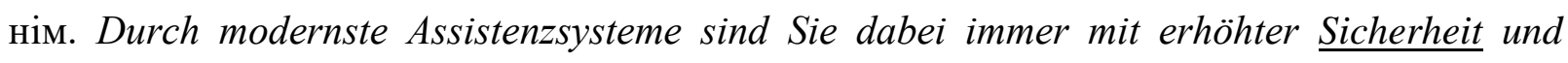
größtem Komfort unterwegs...(Vogue, April 2015) '3 новими системами допомоги Ви завжди знаходитесь у підвищеній безпеці з великим комфортом в дорозі...'

Лексичні засоби можуть також бути використані в складі стилістичних (метафори, гіперболи і т. ін.) або синтаксичних (однослівні, односкладні речення, парцеляція, еліпсис) засобів для посилення акценту на них, напр., 
нім. Das пеие BMW 2er Coupé: Fahrfreude verdichtet. Das Original ist zurück. Im neuen BMW 2er Coupé leben die Gene des legendären BMW 2002 weiter. Kompromisslos sportlich. Dynamisch designt. Entdecken Sie ehemalige Präzision und intensive Emotionen. Erleben Sie das neue BMW 2er Coupé und finden Sie ihre eigenen zwei Worte. (Der Spiegel № 13, 2014) 'Новий BMW Coupé 2 серії: Із задоволенням за кермом. Оригінал повернувся. В новому BMW Cоире́ 2 серії живуть гени легендарного $B M W$ 2002. Безкомпромісно спортивний. Має динамічний дизайн. Відкрийте для себе колишню точність і інтенсивні емоції. Спробуйте новий BMW Coupé 2 серії та знайдіть для себе власні два слова'.

У поданому рекламному тексті німецькою мовою для забезпечення більш інтенсивного ефекту від тактики «акцентування уваги на потребах покупця» та кращого сприйняття лексики, що вказує на високий статус автомобіля, застосовуються такі мовні засоби: стилістичні (метафора leben die Gene des legendären BMW 2002 weiter 'живуть гени легендарного BMW 2002', яка вказує на те, що марка автомобіля має свою давню історію, що, з одного боку, викликає більше довіри, а, з іншого боку, піднімає статус автомобіля в очах реципієнта), синтаксичні (неповні речення Kompromisslos sportlich. Dynamisch designt. 'Безкомпромісно спортивний. Має динамічний дизайн').

У наступному прикладі за основу була взята відома споживачу з дитинства казка про Білосніжку:

нім. Spieglein, Spieglein an der Wand.

Kein Märchen: Ob Leser oder renommierte Jury, am Ende gewinnt immer der Schönste. So wie der Mazda2 beim Goldenen Lenkrad, dem Red Dot Design Award und der Design Trophy... (Cosmopolitan 11.2015)

‘Любе дзеркальце, скажи.

Це не казка: будь то читач або престижне журі, зрештою, завжди виграє найгарніший. Так само, як і Mazda2 у Золотому кермі, Red Dot Design Award та Design Trophy...'

Білосніжка виділялась 3-поміж інших своєю неповторною красою, яка стала предметом заздрості їі мачухи. Тут слід зазначити, що цей рекламний текст був опублікований в журналі Cosmopolitan, орієнтованому на жінок, для яких краса вважається одним з найважливіших критеріїв для досягнення успіху у соціальних відносинах. Використовуючи крилатий вислів Spieglein, Spieglein an der Wand ‘Любе дзеркальце, скажи' автори реклами порівнюють автомобіль Mazda з Білосніжкою, роблячи натяк на те, що інші власники автомобілів будуть заздрити його красі, додаючи впевненості власниці рекламованого автомобіля та задовольняючи іiї потребу в повазі та самоствердженні. Окрім того, в цьому рекламному тексті використана гіпербола gewinnt immer der Schönste 'завжди виграє найгарніший'. 
Ізмалкова А. B.

Мовні засоби вираження тактики «акцентування уваги

на потребах покупия» В рекламному дискурсі

В тексті реклами автомобіля BMW англійською мовою використані такі стилістичні засоби: стійкий вислів easy on the eye 'приємний для ока', анафора Easy on the eye. Easy on your tax return. 'Приємний для ока. Приємний для Вашого податкового звіту.'

англ. Easy on the eye. Easy on your tax return. (New Statesman 20-26 Nov 2015) 'Приємний для ока. Приємний для Вашого податкового звіту.'

У наступній рекламі автомобіля $B M W$ для більшого виділення прикметників, які наголошують на першокласному вигляді автомобіля, був використаний такий стилістичний засіб, як неповні речення:

англ. The graceful sweep of a low, stretched roofline, the muscular stance of a stylish Coupe', with the practicality of five doors. Coupe'. Striking to look at but practical for company car drivers

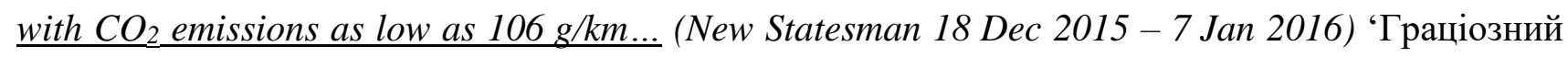
розмах низької, розтягнутої лінії даху, мускулиста посадка стильного Соире' з практичністю п’яти дверей. Соире'. Вражаючий за зовнішністю, але практичний для водіїв автомобілів компанії з викидами $\mathrm{CO}_{2}$ до 106 г/км...'

Аналіз текстів реклами автомобілів німецькою та англійською мовами показав, що актуалізація потреби в безпеці використовується відносно рідко (10\% реклами англійською мовою (6 текстів 3 60) та 3 \% реклами німецькою мовою (2 тексти з 60)), при цьому актуалізація потреб в повазі та самоствердженні через акцентування уваги на високому статусі, зовнішньому вигляді та унікальності автомобіля використовується в $33 \%$ реклами німецькою мовою (20 текстів з 60) та 45 \% реклами англійською мовою (27 текстів з 60). Таке рідке використання актуалізації потреби в безпеці може бути пов’язане з тим, що у сучасному світі потреба в безпеці у людей, які можуть дозволити собі купити автомобіль, вже задовільнена та в більшості випадків не буде досягати потрібного ефекту.

В результаті аналізу частоти використання мовних засобів вираження тактики «акцентування уваги на потребах покупця» при реалізації стратегії маніпуляції в німецькій мові було виявлено 88 одиниць мовних засобів, що характерні для цієї тактики. 3 них 70,45 \% лексичних засобів, що підвищують статус автомобіля (23,86 \% слів іншомовного походження (21 одиниця), 14,77 \% іменників (13 одиниць), 12,5 \% словосполучень (11 одиниць), 12,5 \% прикметників (11 одиниць), 4,55 \% субстантивованих прикметників (4 одиниці)); 2,27 \% лексичних засобів, що наголошують на безпеці автомобіля (2 одиниці); 11,36 \% стилістичних засобів (10 одиниць), 15,91 \% синтаксичних засобів (14 одиниць).

В англійській мові тактика «акцентування уваги на потребах покупця» виражена за допомогою 110 мовних одиниць, 3 них 65,46 \% лексичних засобів, що підвищують статус авто- 
мобіля (26,36 \% прикметників (29 одиниць), 21,82 \% іменників (24 одиниці), 12,73 \% словосполучень (14 одиниць), 2,73\% слів іншомовного походження (3 одиниці), 0,91 \% дієслів (1 одиниця), 0,91 \% прислівників (1 одиниця)); 8,18 \% лексичних засобів, що наголошують на безпеці автомобіля (5,45 \% іменників (6 одиниць), 1,82 \% іменникових словосполучень (2 одиниці), 0,91 \% прикметників (1 одиниця)); 11,82 \% стилістичних засобів (12 одиниць), 15,45\% синтаксичних засобів (16 одиниць).

Таким чином, під час дослідження текстів реклами автомобілів німецькою та англійською мовами були виявлені такі структурні та комунікативні особливості: стратегія маніпуляції в рекламі автомобілів за допомогою тактики акцентування уваги на потребах покупця реалізується, головним чином, на лексичному рівні. Найбільшу роль відіграє лексика, що підкреслює позитивний імідж автомобіля, його високий статус і унікальність, які обіцяють реципієнту вдоволення його потреб у повазі та самоствердженні (напр., прикметники: нім. elegant 'елегантний’, luxuriös ‘розкішний', einzigartig 'неповторний’ / англ. graceful 'граціозний’, elegant 'елегантний', stylish 'стильний', sports 'спортивний’; іменники: нім. Ideallinie 'ідеальна лінія’, Stil ‘стиль', Design ‘дизайн’ / англ. luxury ‘розкіш’, exclusivity ‘ексклюзивність', sophistication 'витонченість' і т. ін.). При цьому синтаксичні та стилістичні засоби грають допоміжну роль. Синтаксичні засоби, роблячи акцент на певній ділянці тексту, звертають увагу реципієнта на певні лексичні засоби (напр., неповні речення: нім. Souverän im Auftritt. 'Незрівнянний за зовнішнім виглядом' / англ. Breathtaking by design. 'Захоплюючий дизайн'). Стилістичні засоби слугують для кращого запам'ятовування рекламного тексту (напр., нім. гіпербола Das Beste kennt keine Alternative 'Краще не знає альтернатив', анафора Mach es besser. Mach es mit Stil. 'Роби це краще. Роби стильно', англ. анафора Easy on the eye. Easy on your tax return. 'Приємний для ока. Приємний для Вашого податкового звіту’, метафора Lincoln MKZ (...) wears a refreshingly bold look on its face 'Lincoln MKZ (...) має освіжаюче сміливий вигляд’).

До перспектив подальших досліджень може належати зіставний аналіз особливостей рекламного дискурсу в німецькій, українській та англійській мовах, а також дослідження структурних та комунікативних особливостей інших тактик, за допомогою яких реалізується стратегія маніпуляції.

\section{СПИСОК ЛІТЕРАТУРИ}

1. Гулак Т. В. Ценностные структуры современного рекламного дискурса (на материале российской коммерческой и политической рекламы): дисс. ... канд. филол. наук. Харьков, 2004. 103 c.

2. Ученова В. В., Старых Н. В. История рекламы. М.: ЮНИТИ, 1999. URL: http://inpiskr.ucoz.ru/_ld/0/14____pdf (дата обращения: 09.01.2019). 
3. Попова Е. С. Структура манипулятивного воздействия в рекламном тексте. Известия Уральского государственного университета. Екатеринбург, 2002. № 24. С. 276-288.

4. Janich, N. (2012) Werbekommunikation pragmatisch. Handbuch Werbekommunikation. Sprachwissenschaftliche und interdisziplinäre Zugänge. Tübingen: Narr Francke Attempto Verlag $\mathrm{GmbH} \& \mathrm{Co} . \mathrm{KG},=.508 \mathrm{~S}$.

5. Kirchler, E. (1999) Wirtschaftspsychologie. München: Psychologie Verlags Union. 450 S.

6. Maslow, Abraham H. (1970) Motivation and Personality. New York: Harper \& Row,=. 369 S.

7. Spieß, E. (2008) Psychologische Aspekte der Werbung. Werbung und Werbesprache: eine Analyse im interdisziplinären Kontext / Béatrice Dumiche (Hrsg.). Pro lingua; 40 Wilhelmsfeld: Egert. $341 \mathrm{~S}$.

\section{Anna Izmalkova LANGUAGE MEANS TO EXPRESS THE COMMUNICATIVE TAC- TIC OF "FOCUSING ON PURCHASER'S NEEDS" IN ADVERTISING DISCOURSE}

The relevance of the study lies in the increased interest in researching advertisements, as well as its manipulative features. The study of the communicative aspects of advertising attracted the attention of many linguists (N. Janich, G. Cook, G. Myers, H. Kaftanjiev etc.). However, not all aspects of this issue are sufficiently covered in the scientific literature. Despite the popularity of this topic, there is still no clear division of communicative strategies and tactics used to implement advertising discourse, as well as sufficient study of lexical, syntactic and stylistic means significant to each of these tactics in scientific papers.

The purpose of the article is to identify the structural and communicative peculiarities of the texts of automobile advertising in the German and English languages.

Specific of researched subject provides the using of: contextual-interpretative and pragmatic text analysis to point out motives and goals of the advertising texts' author, as well as to evaluate the efficiency of the chosen communicative tactic's influence on a recipient; content-analysis to determine the frequency of using of certain language means.

During the conducted research the following structural and communicative features were found: 1) the strategy of manipulation in the automobile advertisements using the tactic of "focusing on purchaser's needs" is realized mainly on the lexical level; 2) lexical means are the most important, as they emphasize the positive image of the car, its high status and uniqueness, satisfying recipient's needs for respect and self-esteem; 3) syntactic and stylistic means play a secondary role: syntactic means, focusing on a certain section of the text, draw attention of the recipient to certain lexical means; stylistic means serve for better memorizing of an advertising text.

The methods of the study may be used in studying of the structural and communicative peculiarities of other communicative tactics and strategies, as well as in comparative analysis of the advertising discourse in the German, English and other languages.

Keywords: communicative strategy, communicative tactic, advertising discourse, advertising text, language manipulation, needs

\section{Vitae}

Anna Izmalkova

Assistant at the Germanic Philology Department, Faculty of Foreign Languages, Vasyl' Stus Donetsk National University, Ukraine.

Correspondence: a.izmalkova@donnu.edu.ua 